University of Wollongong

Research Online

Faculty of Business - Papers (Archive)

Faculty of Business and Law

2013

Thai manufacturing small and medium sized enterprise technical efficiency: evidence from firm-level industrial census data

Teerawat Charoenrat

Khon Kaen University, tc888@uowmail.edu.au

Charles Harvie

University of Wollongong, charvie@uow.edu.au

Yot Amornkitvikai

Rangsit University, ya979@uow.edu.au

Follow this and additional works at: https://ro.uow.edu.au/buspapers

Part of the Business Commons

Research Online is the open access institutional repository for the University of Wollongong. For further information contact the UOW Library: research-pubs@uow.edu.au 


\title{
Thai manufacturing small and medium sized enterprise technical efficiency: evidence from firm-level industrial census data
}

\author{
Abstract \\ Thai manufacturing small and medium sized enterprises (SMEs) face intense competition in domestic \\ and foreign markets. Given their importance to the economic development of the country it is important \\ to have a clear understanding of their readiness to face the rigors of international competition, including \\ the barriers and specific problems that they face. This study uses a stochastic frontier analysis (SFA) and \\ technical inefficiency effects model to analyze the technical efficiency of Thai manufacturing SMEs and \\ key factors impacting upon it. Analysis of cross-sectional data from a 2007 census of Thai manufacturing \\ SMEs indicates that their weighted average technical efficiency is approximately 50 percent, signifying a \\ high level of technical inefficiency which is reducing potential output. The inefficiency effects model \\ reveals that firm size, firm age, skilled labor, ownership characteristics and location are firm-specific \\ factors that significantly affect the technical inefficiency of production. Key measures to improve the \\ technical efficiency of Thai manufacturing SMEs are an adequate supply of inputs, access to credit \\ facilities, extensive infrastructural development and training programs for employees.
}

\section{Keywords}

era2015, manufacturing, level, industrial, census, data, small, medium, sized, enterprise, technical, efficiency, evidence, thai, firm

\section{Disciplines \\ Business}

\section{Publication Details}

Charoenrat, T., Harvie, C. \& Amornkitvikai, Y. (2013). Thai manufacturing small and medium sized enterprise technical efficiency: evidence from firm-level industrial census data. Journal of Asian Economics, 27 (August), 42-56. 


\title{
Thai Manufacturing Small and Medium Sized Enterprise Technical Efficiency: Evidence from Firm-level Industrial Census Data
}

\author{
Teerawat Charoenrat $^{\mathbf{a}} \quad$ Charles Harvie $^{\mathbf{b}} \quad$ Yot Amornkitvikai $^{\mathbf{c}}$
}

\begin{abstract}
Thai manufacturing small and medium sized enterprises (SMEs) face intense competition in domestic and foreign markets. Given their importance to the economic development of the country it is important to have a clear understanding of their readiness to face the rigors of international competition, including the barriers and specific problems that they face. This study uses a stochastic frontier analysis (SFA) and technical inefficiency effects model to analyze the technical efficiency of Thai manufacturing SMEs and key factors impacting upon it. Analysis of cross-sectional data from a 2007 census of Thai manufacturing SMEs indicates that their weighted average technical efficiency is approximately 50 percent, signifying a high level of technical inefficiency which is reducing potential output. The inefficiency effects model reveals that firm size, firm age, skilled labor, ownership characteristics and location are firm-specific factors that significantly affect the technical inefficiency of production. Key measures to improve the technical efficiency of Thai manufacturing SMEs are an adequate supply of inputs, access to credit facilities, extensive infrastructural development and training programs for employees.
\end{abstract}

Keywords: Technical Efficiency; Stochastic Frontier Analysis (SFA); Small and Medium sized Enterprises (SMEs); Manufacturing Industry; Thailand

JEL classification: C31, C87, D24, L6, O12

\footnotetext{
${ }^{a}$ Lecturer, Director, Centre for Entrepreneurship, Innovation and SME Development in the ASEAN Region, Nong Khai Campus, Khon Kaen University, Nong Khai, 4300, Thailand, Phone: +66 4241 5600, Fax: +66 42415699 , Email: tc888@uowmail.edu.au, teerawat.c@nkc.kku.ac.th.

${ }^{\mathrm{b}}$ Associate Professor, Director, Centre for Small Business and Regional Research, School of Economics, University of Wollongong, NSW, 2522, Australia, Phone: +61 242 213702, Fax: +61 242 213725, Email: charvie@uow.edu.au.

${ }^{\mathrm{c}}$ Lecturer, Associate Dean, Faculty of Economics, Rangsit University, Pathumtani, 10120, Thailand, Phone: +662997 2200 ext. 1237, Email: yot.amorn@gmail.com.

The authors would like to express their sincere gratitude to an anonymous referee and George E. Battese for comments received on earlier drafts of this paper. Any remaining errors are solely those of the authors.
} 


\section{Introduction}

The contribution of small and medium sized enterprises (SMEs) to the Thai economy in terms of business numbers, employment, income and economic growth increased rapidly from $1994^{1}$ to 2008. Their total number increased from 438,805 in 1994 to $2,827,633$ in 2008 . By 2008 they represented over 99 percent of all business establishments in the country, and were particularly dense in the trade and repairs, services and manufacturing sectors. On average they employed more than 7 million workers annually over the period 1994 to 2008 , equivalent to more than 73 percent of total employment in the private sector ${ }^{2}$, and contributed 37.9 percent of total GDP by $2008^{3}$ (Office of Small and Medium Enterprises Promotion (OSMEP), 2008). They are now generally recognized as being the most significant enterprises in accelerating Thai economic growth and development (Dhanani and Scholtès, 2002; Wiboonchutikula, 2002; Ha, 2006). SMEs also play important roles and functions in assisting large enterprises, particularly in the context of regional production networks (Regnier, 2000; Brimble et al., 2002; Mephokee, 2003; OSMEP, 2007a; OSMEP, 2008), by being key sources of goods, services, information and knowledge (Regnier, 2000). SMEs also contribute to regional development, poverty alleviation and economic empowerment for minorities and women (Harvie, 2008). SMEs are, therefore, the backbone of the Thai economy, contributing greatly to the social and economic development of the country (Brimble et al., 2002; Huang, 2003; Sahakijpicharn, 2007).

While SMEs are a major force in Thailand's economy, they face a number of severe barriers to their further development. These include: access to finance, marketing, exporting, information technology (IT), innovation, human resource development, management and/or administration skills, access to skilled labor, and government bureaucracy and regulations

\footnotetext{
${ }^{1}$ Data collection for Thai SMEs only commenced in 1994.

${ }^{2}$ In 2008 the manufacturing, services, and trade and repairs sectors contributed 38.8, 33.6, and 27.4 percent of total SME employment, and unspecified enterprises contributed 0.2 percent of all employment.

3 The contribution of SMEs to GDP, at current prices, was approximately 39.0 percent on average of total GDP over the extended period 1999-2008 (OSMEP, 2008).
} 
(OSMEP, 2001; Brimble et al., 2002; Harvie and Lee, 2002; OSMEP, 2008). They also face significant disadvantages. For instance, a large number confront difficulties in gaining access to government funding and credit institutions, because of their limitation in size, lack of fixed assets, and lack of transparency and business plans (Sarapaivanich, 2003; Theingi, 2004; OSMEP, 2007b). Moreover, most SMEs are family-owned with a traditional style and technology in both production and management, and only a small number utilize IT and innovation in their business. As a consequence Thai SMEs are experiencing increased difficulty in competing effectively with, for example, SMEs from China and Taiwan, which have more readily adopted IT and innovation as part of their competitiveness strategy (Mephokee, 2003; OSMEP, 2004).

Despite their obvious importance, little research has been conducted on the competitiveness and efficiency of Thai SMEs, particularly in terms of technical efficiency, and significant factors impacting on this. This study rectifies this gap by empirically estimating 1) the technical efficiency of Thai manufacturing SMEs in aggregate, by size of manufacturing SMEs (small and medium) and by sub-manufacturing sectors as classified by the Standard International Trade Classification (SITC) Revision 4, 2) firm-specific factors contributing to the technical inefficiency of Thai manufacturing SMEs in aggregate, by size of manufacturing SMEs (small and medium) and by sub-manufacturing sectors as classified by SITC Revision 4. Potential firm-specific factors contributing to the technical inefficiency of Thai manufacturing SMEs are drawn from the literature and include: firm size; firm age; skilled labor; location (municipality or nonmunicipality); region of location (i.e., Bangkok, central and vicinity, northern and north-eastern provinces); and ownership characteristics (i.e., individual proprietor, juristic partnership, limited company, state-enterprise, or co-operative). This study also 3) identifies appropriate policies to improve Thai SME technical efficiency. The analysis is conducted using firm-level data obtained 
from the 2007 industrial census ${ }^{4}$, conducted by the National Statistical Office (NSO) of Thailand, consisting of 73,931 observations.

The structure of the paper is as follows. Section 2 conducts a brief overview of Thailand's manufacturing SMEs including their definition as used in this study and their contribution to the economy. Section 3 explains the methodology used and the concept of technical efficiency. Section 4 reviews data and key variables required for derivation of a stochastic frontier production function. Econometric models and hypothesis tests are highlighted in Sections 5 and 6, respectively. Empirical results are summarized and discussed in Section 7. Policy implications and conclusions are presented in Section 8 and Section 9, respectively.

\section{Thailand's Manufacturing Small and Medium Sized Enterprises - an Overview}

\subsection{Definition}

The Ministry of Industry Regulation of 11 September 2002 adopted employment or fixed assets, excluding land, as criteria in defining Thai SMEs (Brimble et al., 2002; OSMEP, 2003). Thus, from Table 1, an enterprise employing up to 50 workers or with fixed assets, excluding land, not exceeding $\mathrm{THB}^{5} 50$ million (approximately US\$1.65 million) in the manufacturing sector, is considered a small enterprise. An enterprise employing between 51-200 workers or with fixed assets, excluding land, greater that THB 50 million up to THB 200 million (that is greater than US\$1.65 million up to US\$6.6 million approximately) is defined as a medium sized enterprise (Mephokee, 2003; OSMEP, 2003). A similar definition is used for SMEs in the services sector, while the definition is slightly different for SMEs in the wholesale and retail sectors.

\section{<Table 1 about here>}

\footnotetext{
${ }^{4}$ Firm-level data in the 2007 industrial census covered the operations of firms from $1^{\text {st }}$ January 2006 to $31^{\text {st }}$ December 2006 (NSO, 2010).

5 Thai baht (THB)
} 


\subsection{Contribution to the Economy}

The contribution of Thai manufacturing SMEs to the economy has traditionally been important in terms of business numbers, employment, output and exports. This can be shown with the aid of Table 2. While the contribution of SMEs to total business numbers remained stable at around 99.6 percent over the period 2001-2008, the contribution of manufacturing SMEs to total SMEs and to overall business numbers has experienced a decline. This is particularly noticeable since 2006, where the contribution of manufacturing SMEs to total SMEs fell from around 30.7 percent in 2006 to around 20 percent by 2008. A similar development is apparent in terms of their contribution to overall businesses. The hiatus of manufacturing SMEs, in terms of significance to overall business numbers, occurred in 1997 before the full effects of the Asian financial crisis began to have an impact. They have subsequently never regained such a level of importance.

In terms of the SME contribution to employment, we can observe from Table 2 that for the period after the Asian financial crisis these enterprises generated around three-quarters of total employment in the economy. Manufacturing SMEs have made an important contribution to this, contributing well over one-third of total employment generated by all SMEs with the exception of the years 1994, 1999 and 2003. As with the contribution to business numbers the hiatus of manufacturing SMEs to employment occurred just before the onset of the Asian financial crisis, when they contributed almost 46 percent of total SME employment or 35 percent of total employment in 1997. Subsequently this contribution has declined, although remaining important at around 38-39 percent of total SME employment or 30 percent of total economy employment over the period $2005-2008^{6}$.

From Table 2 it can also be observed that the SME sector contributed around 38-40 percent of GDP, at current prices, over the period 1999-2008, of which manufacturing SMEs contributed

\footnotetext{
${ }^{6}$ Latest figures for 2009 indicate that manufacturing SMEs contributed 34.2 percent of SME employment, equivalent to 27 percent of total employment.
} 
between 23-32 percent equivalent to between 9-12 percent of overall GDP during this period. Since 2003 the contribution of manufacturing SMEs to GDP has remained fairly stable at around 11-12 percent. Consequently, the contribution of manufacturing SMEs to overall GDP continues to remain important.

The Thai authorities do not compile statistics on the exports of SMEs by sector of activity. However, we can make some general observations based upon the data provided in Table 2. The overall SME sector contributed 31 percent of total exports in 2008, indicative of a significant decline from a peak of around 45 percent in 2002. It can be reasonably suggested that the bulk of SME exports are in the form of agricultural and manufactured products. This sharp decline in the contribution of SMEs to overall exports is indicative of the increased difficulties being experienced by Thailand's SMEs in international markets, as they struggle to remain competitive in the face of intense competition from rapidly developing regional economies, such as China, India, Vietnam and Indonesia, which have much lower labor costs. It is also a reflection of the poor performance of Thai SMEs in upgrading their knowledge and skills, technology, innovation and value adding activities.

A primary aim of this study is to analyze in detail the competitiveness performance of Thai manufacturing SMEs in particular, as measured by their technical inefficiency. This is an important issue as these enterprises continue to make an important contribution to output and employment.

\section{<Table 2 about here>}

\section{Methodology}

Measuring the technical efficiency of firms in an industry can be undertaken by non-parametric or parametric approaches. Data Envelopment Analysis (DEA) is a non-parametric approach that makes no assumptions concerning the form of the production function. Instead, the best practice function is obtained empirically from observed inputs and outputs. DEA precludes the possibility 
of evaluating the marginal products and elasticity of substitution of the production technology (Coelli, 1996b; Admassie and Matambalya, 2002; Coelli et al., 2005; Arunsawadiwong, 2007; Zahid and Mokhtar, 2007). Stochastic Frontier Analysis (SFA), on the other hand, is a parametric approach where the form of the production function is assumed to be known or is estimated statistically. SFA also allows other parameters of the production technology to be explored. The advantage of this approach is that hypotheses can be tested with statistical rigor given that the relationships between inputs and outputs follow known functional forms. When compared to the conventional econometric approach the SFA approach is superior, in that it estimates the 'best practice' technology upon which the production function concept is based while the former is based on 'averaging' estimators (Admassie and Matambalya, 2002; Coelli et al., 2005; Arunsawadiwong, 2007; Zahid and Mokhtar, 2007). Therefore, a conventional econometric model may produce results that are fundamentally inconsistent with the definition of the production function (Coelli et al., 2005; Arunsawadiwong, 2007).

Hence, SFA is applied in this study using the maximum likelihood method to predict technical efficiency and estimate the technical inefficiency effects of Thai manufacturing SMEs. The maximum likelihood method has desirable large-sample (or asymptotic) properties (Coelli et al., 2005; Amornkitvikai and Harvie, 2011) and is preferred to other estimation techniques in computing measures of technical efficiency, such as ordinary least squares (OLS) and corrected ordinary least squares (COLS) (Coelli et al., 2005, p245; Amornkitvikai and Harvie, 2011). OLS estimates cannot be utilized to calculate the technical efficiency of firms, since the estimated intercept coefficient obtained from the OLS is biased downwards even though the estimated slope coefficients are consistent.

We have, therefore, used the econometric package Frontier version 4.1 to estimate stochastic frontier production functions (Coelli, 1996a) using the method of maximum likelihood 
to calculate a wide variety of stochastic frontier models, based on a Cobb Douglas production function, using cross sectional firm level data (Coelli et al., 2005).

\section{Data and Variables}

This study used 2007 industrial census data collected by the National Statistical Office of Thailand, concerning enterprises engaged in manufacturing industry activities only (NSO, 2011b) ${ }^{7}$. The 2007 industrial census covered establishments with 10 employed persons or more in all regions throughout the nation. The census is based on a Stratified Systematic Sampling methodology ${ }^{8}$ Regions and provinces or cities were constituted as strata while type of industrial activities and groups of industrial establishment were constituted sub-stratum. The sampling units were establishments. The sample selection of establishments was completed by systematic sampling and performed separately and independently in each sub-stratum and groups of industrial establishment. An interview method was employed in the data collection (NSO, 2010). Therefore, the 2007 industrial census targeted 73,931 manufacturing firms which were small, medium and large enterprises. Importantly, this study only focuses upon manufacturing SMEs so the sample size was reduced to 56,441 after we excluded large firms, SMEs with missing values, nonresponses, negative values and intentional misreporting and errors arising at coding and data entry stages (NSO, 2010). This is essential in order to ensure adequacy of data in order to complete the SFA analysis. For more information on how the census is compiled or conducted see National Statistical Office of Thailand (NSO, 2010).

Data for Thai manufacturing SMEs are categorized in three ways: by size of SME (small or medium), by aggregate manufacturing SMEs, and by sub-manufacturing sectors classified by SITC

\footnotetext{
${ }^{7}$ Summary statistics for key variables used in this study by size of SME (small or medium) and by standard international trade classification from the industrial census are available from the authors on request.

8 Hence the 2007 Industrial Census for Thailand is not a census in the strict sense that data from a complete enumeration of the population of all enterprises with employment of 10 or more workers has been conducted, rather it consists of data obtained from a sample of such enterprises.
} 
Revision 4 and includes SITC 0: Food and live animals, SITC 1: Beverages and tobacco, SITC 2: Crude materials, inedible, except fuels, SITC 3: Mineral fuels, lubricants and related materials, SITC 5: Chemicals and related products, SITC 6: Manufactured goods classified by material, SITC 7: Machinery and transport equipment, SITC 8: Miscellaneous manufactured articles. The industrial census does not cover SITC 4: Animal, vegetable oils and waxes.

\subsection{Variables}

Data extracted from the census are those pertaining to the estimation of a Cobb-Douglas production function, and include value added $(Y)$, labor input $(L)$ and capital input $(K)^{9}$. Value added is measured as the value of gross output minus intermediate consumption and is used for output production. The formula for value added is calculated by subtracting intermediate inputs (i.e., value of raw materials, purchased parts and components) from output (i.e., output produced or sales revenue). Labor input is measured by the number of workers in the firm, including owners or partners, unpaid workers, skilled and unskilled labor. Hence the total number of workers is used as the proxy for labor input. Capital input is measured as the net value of fixed assets after deducting accumulated depreciation at the end of the year. The net value of fixed assets is a combination of land, buildings, construction, machinery and equipment, vehicles and office appliances.

\footnotetext{
${ }^{9}$ This study used other measures of output (e.g. sales revenue) and three different types of input (e.g. capital (fixed assets), wages and salaries (wage bill) and intermediate inputs), to conduct the empirical analysis. However, they produced insignificant results in terms of the goodness of fit. This study also tested for the validity of the technical inefficiency term and a stochastic frontier production function by identifying the value of the gamma parameter $(\gamma)$. Therefore, in this study, output as measured by value added and two inputs- capital (the value of fixed assets) and labor (the total number of workers) are preferred in the conduct of this analysis.
} 


\section{Model Specification}

A Cobb-Douglas production function can be used to predict technical efficiency and to estimate inefficiency effects models, such as for our sample of Thai manufacturing SMEs, using crosssectional firm level data ${ }^{10}$. A Cobb-Douglas production function, using cross-sectional data, may be expressed as (Coelli, 1996a):

$$
\ln Y_{i}=\beta_{0}+\beta_{1} \ln \left(K_{i}\right)+\beta_{2} \ln (L)+\left(V_{i}-U_{i}\right)^{11} \quad, \mathrm{i}=1, \ldots, \mathrm{N}
$$

where $Y_{i}$ denotes value added, $K_{i}$ represents net fixed assets, $L_{L}$ represents the total number of employees, $V_{i}$ are random error terms that are assumed to be independently and identically distributed normal random variables with zero means and variances, $\left(V_{i} \sim \operatorname{iid} N\left(0, \sigma_{v}^{2}\right)\right)$ and are assumed to be independently distributed of the $U_{i}$. The $U_{i} \mathrm{~s}$ are non-negative random variables accounting for technical inefficiency in the production function that are assumed to be independently distributed, such that $U_{i}$ is defined by the truncation of the normal distribution with mean $\mu_{i}$ and variance $\sigma_{\mu}^{2}$. In addition, $V_{i}$ and $U_{i}$ are assumed to be independently distributed for all firms (i = 1, 2,..., N) (Battese and Coelli, 1995; Coelli, 1996a; Coelli et al., 2005; Tran et al., 2008). If $U_{i}$ is equal to zero, it can be defined that the firm is totally technically efficient at its maximum output level given the inputs used. If $U_{i}$ is greater than zero, it can be defined that the firm is technically inefficient (Coelli, 1996a; Kumbhakar and Lovell, 2000; Tran et al., 2008). The subscript $_{i}$ refers to firms, $\beta_{0}$ represents the intercept term, $\beta_{1}$ represents the coefficient estimates of capital input and $\beta_{2}$ represents the coefficient estimates of labor input.

The potential firm specific-factors that could influence technical efficiency are modeled in an inefficiency functional form as follows:

$$
\mu_{i}=\delta_{0}+\delta_{1} \text { size }_{i}+\delta_{2} \text { age }_{i}+\delta_{3} \text { skill }_{i}+\delta_{4} \text { location }_{i}+\delta_{5} \text { bangkok }_{i}+\delta_{6} \text { central }_{i}
$$

\footnotetext{
${ }^{10}$ A preliminary analysis using a Translog production function was also conducted, but the authors did not proceed with this approach due to the unsatisfactory results obtained which were difficult to accept or explain.

${ }^{11}$ The Cobb-Douglas production function will be estimated simultaneously with the inefficiency effects model as indicated in Equation 2.
} 


$$
\begin{aligned}
& +\delta_{7} \text { northern }_{i}+\delta_{8} \text { north-eastern }_{i}+\delta_{9} \text { individual }_{i}+\delta_{10} \text { juristic }_{i} \\
& +\delta_{11} \text { limited }_{i}+\delta_{12} \text { state }_{i}+\delta_{13} \text { co-operative }_{i}
\end{aligned}
$$

where size is a dummy variable that takes the value 1 for small enterprises employing up to 50 workers and 0 for medium enterprises employing between 51-200 workers. Firm age is the number of years since a firm's establishment. Skill is the ratio of skilled labor in the production process to total labor input. Location is a dummy variable for municipal ${ }^{12}$ area that takes the value 1 if a firm is located in a particular municipal area and 0 otherwise, to control for differences in location. A dummy variable for Bangkok takes the value 1 if a firm is located in Bangkok and 0 otherwise. Central is a dummy variable for the central region that takes the value 1 if a firm is located in the central $^{13}$ region and 0 otherwise. Northern is a dummy ${ }^{14}$ variable for the northern region that takes the value 1 if a firm is located in the northern region and 0 otherwise. A dummy variable for the north-eastern region takes the value 1 if a firm is located in the north-eastern region and 0 otherwise $\mathrm{e}^{15}$. Individual is a dummy variable that takes the value 1 for an individual proprietor and 0 otherwise. A dummy variable for juristic partnership takes the value 1 if a firm is a juristic partnership and 0 otherwise. Limited is a dummy variable that takes the value 1 for a limited liability company and 0 otherwise. State is a dummy variable that takes the value 1 for a state owned enterprise and 0 otherwise. A dummy variable for a co-operative takes the value 1 if a firm is a cooperative and 0 otherwise.

\footnotetext{
${ }^{12}$ With respect to the municipal (town or city) dummy variable, the dummy variable takes a value of 1 for SMEs located in urban areas and zero for SMEs located in rural areas for the entire nation (NSO, 2011).

${ }^{13}$ The National Statistics Office of Thailand (2011) included the Eastern region in the Central region in the 2007 industrial census.

${ }^{14}$ The Southern region is excluded from the model in order to avoid the dummy trap.

15 Focusing on the regional (i.e., Bangkok, Central and Vicinity, Northern and North-eastern regions) dummy variables, the Office of National Research Council of Thailand (2012) divides Thailand into six geographical regions, including Bangkok area, Central and Vicinity regions, Northern region, North-eastern region, Eastern region and Southern region. Each one of these regions is different from the others in terms of population, social and economic development, natural features and basic resources (the Office of National Research Council of Thailand, 2012). In addition, the 2007 industrial census includes all SMEs located in urban and rural areas in each region of Thailand (NSO, 2011).
} 
The coefficients of the frontier and inefficiency effects model can be measured using the maximum likelihood method. The maximum likelihood function is defined in terms of the variance parameters as follows (Battese and Corra, 1977; Coelli et al., 2005):

$$
\sigma^{2} \equiv \sigma_{v}^{2}+\sigma_{u}^{2} \text { and } \gamma \equiv \sigma_{u}^{2} / \sigma^{2}
$$

where $\gamma$ represents the share of technical inefficiency in the overall residual variance. If the value of $\gamma$ is close to zero deviations from the frontier are largely attributable to noise, whereas a value close to unity indicates considerable technical inefficiency (Coelli et al., 2005; Tran et al., 2008).

\section{Hypothesis Tests}

The estimation of a stochastic frontier production function can be used to test the validation of three null hypotheses: (1) absence of technical inefficiency effects (2) absence of stochastic inefficiency effects (3) insignificance of joint inefficiency variables. Formal hypotheses tests associated with the stochastic production function and technical inefficiency effects models are presented in Tables 3, 4 and 5, respectively. The three hypotheses were tested using the generalized likelihood-ratio test (LR test), which can be defined as (see Kim, 2003; Coelli et al., 2005; Tran et al., 2008):

$$
\lambda=-2\left\{\log \left[L\left(H_{0}\right)\right]-\log \left[L\left(H_{1}\right)\right]\right\}
$$

where $\log \left[L\left(H_{0}\right)\right]$ and $\log \left[L\left(H_{1}\right)\right]$ are the values of a log-likelihood function for the frontier model under the null hypothesis $\left(\mathrm{H}_{0}\right)$ and the alternative hypothesis $\left(\mathrm{H}_{1}\right)$. The LR test statistic follows an asymptotic chi-square distribution with parameters equal to the number of restricted parameters imposed under the null hypothesis $\left(\mathrm{H}_{0}\right)$, except hypotheses (1) and (2) for which the test statistic is a mixture of chi-square distributions (Kodde and Palm, 1986). Hypotheses (1) and (2) involve the restriction that $\gamma$ is equal to zero which defines a value on the boundary of the parameter space (Coelli, 1996a, p6). 
Table 3 exhibits results for hypothesis tests for aggregate manufacturing SMEs ${ }^{16}$. From Table 3 the first null hypothesis, which specifies that technical inefficiency effects are absent from the model is strongly rejected at the 1 percent level of significance, given the assumptions of the technical inefficiency effects model of equation (2) as specified above. This specifies that no reduced form of this model is an adequate representation of the data for aggregate manufacturing SMEs. The second null hypothesis, that inefficiency effects are not stochastic, is strongly rejected, implying that the estimated parameters can be defined in the technical inefficiency effects model given by equations (1) and (2). The last null hypothesis, specifying that all estimated parameters of the explanatory variables in the inefficiency effects model are equal to zero, is strongly rejected at the 1 percent level of significance for aggregate manufacturing SMEs, indicating that the joint inefficiency effect of the explanatory variables is statistically significant, as defined by equations (1) and (2).

\section{<Table 3 about here>}

Table 4 summarizes the results for a number of null hypotheses relating to the SME sector by size of SME. The first null hypothesis, identifying that technical inefficiency effects are absent from the model, is strongly rejected at the 1 percent level of significance, given the assumption of the technical inefficiency effects model of equation (2), as modified above. This indicates that no reduced form of this model is an adequate representation of the data for size of SME (small and medium). The second null hypothesis, that inefficiency effects are not stochastic, is strongly rejected, meaning that the technical inefficiency effects model is applicable for size of SMEs,

\footnotetext{
${ }^{16}$ Most studies (Alvarez and Crespi, 2003; Minh et al., 2007; Tran et al., 2008; Pham et al., 2009; Le, 2010; Le and Harvie, 2010) on technical efficiency present results for SMEs at the aggregate level only. This study presents results for both the aggregate and disaggregated levels. A goodness of fit of each of the estimates is measured by the gamma parameter (Coelli et al., 2005; O'Donnell et al., 2009). The value of this for aggregate, small and medium sized enterprises is shown in Table 6. Where the gamma parameter is the same for both aggregate and small firms, but noticeably higher for medium sized enterprises.
} 
given by equations (1) and (2). The last null hypothesis specifies that the inefficiency effects are not a linear function in the model. The null hypothesis is strongly rejected at the 1 percent level of significance for size of SMEs, as defined by equations (1) and (2).

\section{<Table 4 about here>}

Table 5 presents results for hypothesis tests for sub-manufacturing sectors. In Table 5 the first null hypothesis $\left(\mathrm{H}_{0}\right)$, which specifies that technical inefficiency effects are absent from the model, is strongly rejected at the 1 percent level of significance, given the assumption of the technical inefficiency effects model of equation (2), as modified above. This signifies that no reduced form of this model is an adequate representation of the data by sub-manufacturing sectors. The second null hypothesis (3), that inefficiency effects are not stochastic, is strongly rejected at the 1 percent level of significance indicating that the technical inefficiency effects model is applicable for all sub-manufacturing sectors as defined by equations (1) and (2). The last null hypothesis is strongly rejected at the 1 percent level of significance for all sub-manufacturing sectors, implying that the joint inefficiency effect of the explanatory variables is statistically significant, as specified by equations (1) and (2).

\section{$<$ Table 5 about here>}

\section{Empirical Results}

Maximum likelihood estimates for the parameters of the stochastic frontier model and inefficiency effects model, as specified by equations (1) and (2), were estimated simultaneously with the econometric package Frontier 4.1 using firm-level industrial census data for 2007. The estimated results for equations (1) and (2) are provided in Tables $6^{17}$ and 7 . The estimation of the technical inefficiency effects model is presented in Table 8.

\footnotetext{
${ }^{17}$ Table 6 refers to estimating the functional forms of the production function separately for small and medium firms. Different parameter values were obtained as well as those for explanatory variables from the technical inefficiency effects model.
} 


\subsection{Results for input elasticities and gamma parameters}

Table 6 presents the results of maximum likelihood estimation for aggregate manufacturing SMEs. The Cobb-Douglas production function for aggregate manufacturing SMEs has positive signs for both capital and labor input, 0.233 and 0.973 respectively, and they are also highly significant at the 1 percent level of significance. The Cobb-Douglas production function reveals increasing returns to scale for aggregate manufacturing SMEs, as the combined value of the estimated input

coefficients is 1.21 . The estimate of the gamma parameter $(\gamma)$ is 0.651 (see Table 6 ), implying that deviations from the stochastic production frontier are due to considerable technical inefficiency (Phan, 2004; Coelli et al., 2005; Tran et al., 2008).

Table 6 also shows the results of maximum likelihood estimation by size of SME. Small enterprises have positive signs for both capital and labor, at 0.220 and 1.045 , respectively, and are highly significant at the 1 percent level of significance. Small enterprises have increasing returns to scale because the combined value of the estimated input coefficients (1.26) is greater than unity. The estimated gamma parameter for small enterprises is 0.653 (see Table 6), specifying that deviations from the stochastic production frontier are due to considerable technical inefficiency. For medium sized enterprises the coefficients of capital and labor are positive, 0.313 and 0.683 respectively, and they are statistically significant at the 1 percent level. Medium sized enterprises tend to have constant returns to scale because the summed value of the estimated input coefficients (0.99) is close to unity. Moreover, the estimate of the variance parameter gamma is 0.787 (see Table 6), indicating that deviations from the stochastic production frontier are mainly due to technical inefficiency. 
Table 6 also indicates noticeably different values for input elasticities ${ }^{18}$ by size of SME. Labor input elasticities are higher for both small and medium sized enterprises in comparison to capital input elasticities in production, and particularly so for small enterprises. Consequently, additional production can be more easily achieved in the case of both small and medium sized enterprises by using relatively more labor input in the production process, and particularly so for small enterprises. We can suggest, therefore, from Table 6, that there is an incentive to use relatively labor intensive production techniques for both sizes of enterprise and that this incentive is even greater for small enterprises. This could be problematic for Thai SMEs in that it may encourage or accentuate the dependence of SMEs on low cost and unskilled labor operating in low income and low value adding activities, and discourage upgrading of technology through capital input acquisition. However, such a conclusion requires a more in depth analysis that goes beyond the present study.

\section{<Table 6 about here>}

Table 7 shows the results for sub-manufacturing sectors classified by SITC Rev. 4. The estimated coefficients of capital and labor are positive and they are strongly significant at the 1 percent level in all sub-manufacturing sectors. The input elasticities of capital and labor reveal increasing returns to scale in six sub-manufacturing sectors, including SITC 0, SITC 1, SITC 2, SITC 5, SITC 6 and SITC 8, because the sum of the estimated input coefficients obtained from the stochastic frontier models are greater than unity. The elasticities of SITC 7 seem to have constant returns to scale. However, it is important to note that there are different elasticities in all submanufacturing sectors. The elasticities of labor in the stochastic production functions are much higher than capital. Elasticities of labor start from 0.82 in SITC 5 and reach 1.05 in SITC 0, while

\footnotetext{
18 With a Cobb-Douglas production function the estimated input coefficients can be used to represent input elasticity in the production function. In addition, a measurement of returns to scale, specified by the combined value of the estimated input coefficients, provides economic meaning, signifying whether firms are operating under constant, increasing, or decreasing returns to scale (Vu, 2003; Griffiths and O'Donnell, 2005; Major, 2008; Amornkitvikai et al., 2010).
} 
capital elasticities range from 0.16 in SITC 8 to 0.31 in SITC 1 . The high values for labor elasticity indicate the importance of labor in the production process and the incentive to use relatively labor intensive means of production. The low capital elasticity value in the production function shows that capital is of lesser importance in production and that there is less incentive to use more capital intensive means of production. The gamma parameter values range from 0.525 in SITC 6 to 0.764 in SITC 5, with the exception of SITC 7. This implies that inefficiency effects are likely to be significant in an analysis of the value of output of SITC 0, SITC 1, SITC 2, SITC 5, SITC 6 and SITC 8 (Coelli, 1995). However, the value of the gamma parameter in SITC 7 was 0.188 , which means that deviations from the production function are mainly attributable to noise (see Table 7).

\subsection{Weighted Average Technical Efficiency}

Tables 6 and 7 also show the weighted ${ }^{19}$ average technical efficiency levels of Thai manufacturing SMEs in ten categories. The weighted average technical efficiency ranges from 67 percent for medium sized enterprises to 44 percent for SITC 2: Crude materials, inedible, except fuels. Medium sized enterprises, therefore, had the highest percentage weighted mean technical efficiency in 2007. The second highest percentage weighted mean technical efficiency is found for SITC 5: Chemicals and related products, with 63 percent. SITC 7: Machinery and transport equipment ranked third at 61 percent weighted mean technical efficiency. The fourth ranked technical efficiency is SITC 1: Beverages and tobacco, with 58 percent. SITC 0: Food and live animals ranked fifth at 54 percent weighted mean technical efficiency. The weighted average technical efficiency of aggregate manufacturing SMEs is 51 percent. Small enterprises and SITC 8: Miscellaneous manufactured articles each achieved 48 percent weighted mean technical efficiency. SITC 6: Manufactured goods classified by material and SITC 2 had 45 and 44 percent weighted

\footnotetext{
${ }^{19}$ Each individual firm's technical efficiency is multiplied by its weighted contribution to value added, and the sum of these is then divided by the number of firms in the sample to give the weighted average technical efficiency.
} 
mean technical efficiency, respectively. Finally, the weighted average technical efficiency of all categories of Thai manufacturing SMEs is 54 percent.

\subsection{Results for Technical Inefficiency Effects}

The estimated results for equations (1) and (2) are shown in Table 8. Negative coefficient signs of the inefficiency effects model represent technical efficiency, so must be converted to positive for technical efficiency.

\subsubsection{Firm Size}

Firm size is one of the important firm-specific factors. Many studies have found that the size of a firm has a positive association with technical efficiency (Lundvall and Battese, 2000; Admassie and Matambalya, 2002; Yang, 2006; Tran et al., 2008). Jovanovic (1982) acknowledged that larger firms are much more efficient than smaller firms. Phan (2004) also emphasized that large firms are able to obtain new technology faster than small firms, because they have less capital constraints. From Table 8 the estimated coefficients for firm size in the technical inefficiency effect models are both significant and negative in five categories, including aggregate manufacturing SMEs, SITC 0, SITC 1, SITC 6 and SITC 8, implying that there is a positive relationship between firm size and technical efficiency in these categories. The significance level of the negative coefficients varies among these categories. The coefficient of aggregate manufacturing SMEs, SITC 0, SITC 1 and SITC 8 are highly significant at the 1 percent level, while the coefficient of SITC 6 is significant at the 5 percent level. Although the estimated coefficients of SITC 2, SITC 5 and SITC 7 are positive, they are not statistically significant.

\section{<Table 7 about here>}

\subsubsection{Firm Age}

Firm age can also contribute to technical efficiency. A number of empirical studies have found that firm age has a positive impact upon technical efficiency (Admassie and Matambalya, 2002; Batra 
and Tan, 2003; Phan, 2004; Tran et al., 2008). The negative coefficients for firm age, as summarized in Table 8, indicate that firm age is positively related to technical efficiency in seven categories, including aggregate manufacturing SMEs, small and medium enterprises, SITC 0, SITC 1, SITC 5 and SITC 8, while there are positive coefficients for SITC 2, SITC 6 and SITC 7. When we consider the significance of the negative coefficient only five categories are statistically significant - aggregate manufacturing SMEs and small enterprises at the 5 percent level, medium sized enterprises, SITC 0 and SITC 5 at the 1 percent level of significance, while SITC 1 and SITC 8 are insignificant. Older firms in these sectors may have greater management experience. They have learned from past mistakes, and are more likely to achieve higher efficiency because of 'learning by doing', and improved managerial skills (Phan, 2004).

On the other hand, firm age can have a negative effect on technical efficiency (Phan, 2004; Le and Harvie, 2010). Estimates of the coefficient for firm age are positive for SMEs operating in SITC 2, SITC 6 and SITC 7, i.e. firm age is negatively related to technical efficiency. Tran (2008) found that firm age was associated with lower efficiency levels in non-state small and medium manufacturing industries in Vietnam ${ }^{20}$. For older firms the learning by doing process could be offset by obsolete technology compared with younger firms (Tran et al., 2008). Pasanen (2007) also found that older firms tend to possess older machinery and equipment, while younger firms have just entered the market and are equipped with modern technology. Some of these factors could well be important in the context of SITC 2, SITC 6 and SITC 7 in Thailand.

\subsubsection{Skilled Labor}

The estimated coefficients for skilled labor, represented by the ratio of skilled labor to total workers, are negative and highly significant at the 1 percent level of significance in nine

\footnotetext{
${ }^{20}$ This is likely to be a characteristic of an economy in transition from plan to market. Older firms are more used to functioning in a planned economy in which the role of the private sector is negligible, and they lack experience in operating in a market economy. In this situation, firm age is not likely to be beneficial.
} 
categories, including aggregate manufacturing SMEs, small enterprises, SITC0, SITC 1, SITC 2, SITC 5, SITC 6, SITC 7 and SITC 8. This implies that skilled labor is positively correlated with improvements in technical efficiency. This finding confirms previous research. For instance, skilled labor is one of the significant factors contributing to SME development in Thailand (Regnier, 2000; Huang, 2003); Admassie and Matambalya (2002) emphasized that skilled labor was positively related to technical efficiency for SMEs in Tanzania; while Zahid and Mokhtar (2007) found that skilled labor had a positive effect on the technical efficiency of Malaysian manufacturing SMEs. Saleh and Ndubisi (2008) also found that a lack of skilled labor is one of the internal challenges in Malaysian SMEs. Krasniqi (2007) similarly found that an internal barrier to SME growth is access to skilled labor.

However, estimates of the coefficients for skilled labor show an unexpected positive sign in one category - medium sized enterprises. The coefficient for this category is statistically significant at the 1 percent level of significance. This indicates that skilled labor has a potentially negative impact on the technical efficiency of medium sized enterprises. While this is not what would be expected it could reflect the fact that such enterprises are working with out of date or labor intensive technology, where additional skilled labor simply exacerbates existing production and technology inefficiencies.

\subsubsection{Municipality}

The estimated coefficients for municipality are negative for nine categories and statistically significant (with different levels of significance) for six of them. The coefficients for aggregate manufacturing SMEs, small enterprises, SITC 0, SITC 2, SITC 6 and SITC 8 are strongly significant at the 1 percent level. The coefficients of SITC 1, SITC 5 and SITC 7 are not significant. These results suggest that municipal area has a positive relationship to technical efficiency. According to Tran et al. (2008) the metropolitan efficiency effect is suggestive of agglomeration economies in the private sector, as a consequence of better availability of educated 
workers and managers, and market opportunities in metropolitan locations relative to nonmetropolitan locations. Many studies show that a municipal area has a positive impact on technical efficiency (Krasachat, 2000; Li and Hu, 2002; Yang, 2006; Le and Harvie, 2010). However, the coefficient for one category in our study is positive, for medium sized enterprises, implying that municipality is negatively related to technical efficiency, although this coefficient is not statistically significant.

\subsubsection{Bangkok Area, Central and Vicinity Regions}

Results concerning the dummy variable for the Bangkok area are negative, as expected for all categories, and are highly significant at the 1 percent level. This indicates that location in the Bangkok area is positively associated with technical efficiency. According to the Office of Small and Medium Enterprises Promotion (2008) the Bangkok area contained the highest number of SMEs over the period 1994 to 2008, accounting for around 30 percent of total SMEs on average. Bangkok is recognized as the major economic centre of the nation and is a regional force in finance and business. For central and vicinity regions the results of the estimated coefficients for this dummy variable are mixed. They are negative in seven categories, (aggregate manufacturing SMEs, medium sized enterprises, SITC 0, SITC 1, SITC 5, SITC 7 and SITC 8), and positive in three (small enterprises, SITC 2 and SITC 6). However, only one category with a negative sign is statistically significant (medium sized enterprises at the 1 percent level). These results suggest that location in the central and vicinity regions are generally positively related to technical efficiency. The central and vicinity regions contain many of Thailand's large businesses and are the focal point of trade and transport (OSMEP, 2008). Central and vicinity regions in three categories, small enterprises, SITC 2 and SITC 6, have positive coefficients, but these are not statistically significant. 


\subsubsection{Northern and North-eastern Regions}

The estimated coefficients for the northern region are positive in all categories and are highly significant at the 1 percent level, except SITC 1. This implies that the location of an SME in the northern region is negatively related to technical efficiency, and that there are significant efficiency disadvantages for SMEs in all categories located in this region that require to be urgently understood and addressed. Despite this, in 2008 the northern region had 479,154 SMEs, or 17 percent of total SMEs, an increase of 79,028 SMEs over 2007. Estimates of the coefficients for the north-eastern region are negative for two categories, medium sized enterprises and SITC 0 , and are positive in eight categories (aggregate manufacturing SMEs, small enterprises, SITC 1, SITC 2, SITC 5, SITC 6, SITC 7 and SITC 8). The coefficients for medium sized enterprises and SITC 0 are not statistically significant. According to the Office of Small and Medium Enterprises Promotion (2008), the north-eastern area had 514,498 SMEs, equivalent to 27.4 percent of all SMEs, on average during 1994 to 2008. The North-eastern area has the highest population in the country (ONRCT, 2012). However, the positive coefficients for aggregate manufacturing SMEs, small enterprises, SITC 1, SITC 2, SITC 5, SITC 6, SITC 7 and SITC 8 indicate that location in the north-eastern region is negatively related with technical efficiency, suggesting major location problems for SMEs in these categories that require to be urgently addressed.

\subsubsection{Individual Proprietor, Juristic Partnership and Limited and Public Limited}

\section{Companies}

The negative coefficients for individual proprietor in all ten categories confirm a positive relationship between individual proprietor and technical efficiency. The coefficients of all ten categories are strongly significant at the 1 percent level, comprising aggregate manufacturing SMEs, small and medium sized enterprises, SITC 0, SITC 2, SITC 5, SITC 6, SITC 7 and SITC 8. The advantages of being an individual or sole proprietorship are many (Buranajarukorn, 2006; Ha, 2006): 1) complete control and decision-making power over a business; 2) sale or transfer of the 
enterprise is at the discretion of an individual or sole proprietor; 3) it requires minimal legal costs to enter the market; 4) it has fewer legal and reporting requirements 5) greater flexibility in adjusting to rapidly changing markets and technology.

The estimated coefficients for a juristic partnership are negative for all categories, and are highly significant at the 1 percent level. This implies that there is a positive relationship between juristic partnership and the technical efficiency of SMEs. Compared to an individual or sole proprietorship, a juristic partnership has the advantage of allowing the owner to draw on the resources and expertise of co-partners who share responsibilities and solve barriers to doing business (Fay, 1998).

Estimates of the coefficients for limited and public limited companies are negative for all categories and strongly significant at the 1 percent level. This can be interpreted to mean that limited and public limited owned companies are positively related with technical efficiency in these ten categories. Ha (2006) suggested that the advantages of limited and public limited companies are: 1) it has a legal existence which separates management from shareholders; 2) a company can continue to trade despite the resignation or bankruptcy of management and its members; 3) new shareholders and investors can be easily incorporated and employees can acquire shares.

\subsubsection{Government and State owned Enterprises}

Coefficients for government and state owned enterprises are positive in seven categories, including aggregate manufacturing SMEs, small and medium enterprises, SITC 2, SITC 6, SITC 7 and SITC 8 and negative for the remaining three (SITC 0, SITC 1 and SITC 5). Coefficients for aggregate manufacturing SMEs, medium sized enterprises, SITC 2 and SITC 8 are statistically significant at the 1 percent level, SITC 6 is significant at the 5 percent level, while SITC 7 is insignificant. These results suggest that there is a negative relationship between government and state owned SMEs and technical efficiency. However, the negative coefficients for SITC 1 and SITC 5 are at the 5 percent 
level of significance and the coefficient of SITC 0 is insignificant, indicating that government and state owned SMEs are positively related to technical efficiency in these categories.

\subsubsection{Cooperatives}

Estimated coefficients for cooperatives are negative for eight categories (aggregate manufacturing SMEs, small and medium enterprises, SITC 0, SITC 1, SITC 5, SITC 6 and SITC 8), while the coefficients of SITC 2 and SITC 7 are positive although only the former is significant. When the level of significance of the negative coefficient is taken into consideration, only four categories are significant at the 1 percent level: aggregate manufacturing SMEs, small enterprises, SITC 0 and SITC 5. The coefficients for the remaining categories are not significant. These results indicate that there is a positive relationship between cooperatives and technical efficiency in these four categories. Thuvachote (2007) suggested that the advantage of being a cooperative are: 1) all shareholders must be active in the cooperative; 2) shareholders have an equal vote at general meetings regardless of their shareholding or involvement; 3) a cooperative is owned and controlled by its members.

\section{<Table 8 about here>}

\section{Policy Implications}

Our results show that Thai manufacturing SMEs across ten categories have a weighted average technical efficiency of 50 percent, indicating high levels of technical inefficiency that are constraining potential output and require policies to: 1) improve input efficiencies to enable firms to operate on their most efficient production frontier given the current state of technology, and 2) shift the existing frontier outward through utilization of improved technology. A number of specific policy recommendations to promote the technical efficiency of Thai manufacturing SMEs are derivable from this study. 
Empirical results from the inefficiency effects model indicate that firm size and firm age are positively and significantly correlated with the technical efficiency of aggregate manufacturing SMEs and for the majority of categories of manufacturing SMEs. There are sectoral exceptions but these are not statistically significant. Increased firm size and growth, therefore, needs to be encouraged since larger size can result in economies of scale and scope, reduced production costs, improved efficiency and competitiveness (Phan, 2004). This has important policy implications in terms of access to inputs including finance, technology and skilled labor to facilitate firm growth ${ }^{21}$. Older firms can be more experienced than younger firms due to superior management experience and knowledge (Pasanen, 2006). This appears to be the case for aggregate manufacturing SMEs, although the coefficient is low, but differs at the sectoral level. This diverging sectoral outcome is likely to be partially due to differing sector characteristics, as firm age is likely to be less important in sectors subject to rapid market and technology change. In such sectors policy should give more emphasis to new firm start-ups

Skilled labor has a positive and significant correlation with the technical efficiency of aggregate manufacturing SMEs for small but not medium sized enterprises and across seven sectoral categories of manufacturing SMEs. A negative correlation between skilled labor and technical efficiency for medium sized enterprises is somewhat unexpected. This could be due, however, to the fact that unless medium sized enterprises upgrade their technology in conjunction with the acquisition of skilled labor there will be no improvement in their technical efficiency. Overall, however, it appears to be an important factor affecting firm efficiency. The second Thai SME promotion plan (2007-2011) aims to implement strategies that will improve the knowledge and skills base of SME personnel to facilitate technology upgrading (OSMEP, 2007b).

\footnotetext{
21 The second Thai SME promotion plan (2007-2011) aimed to create a conducive environment to increase the number of new entrepreneurs, and support efforts to enhance their performance and create business value in order to compete in niche markets (Office of Small and Medium Enterprises Promotion, 2007).
} 
Location in municipal areas and Bangkok is found to have a positive and significant correlation with the technical efficiency of Thai manufacturing SMEs in aggregate and by size. A Bangkok location is consistently found to be significantly and positively correlated with technical efficiency. Location in a municipal area is also positively correlated with technical efficiency but is not statistically significant across all manufacturing sub sectors. These results suggest that there are agglomeration benefits from urban location, which is likely to make it difficult to encourage SME development in non-municipal or rural areas. This has the potential to further exacerbate the ruralurban income, unemployment and political divide in the country (Yang, 2006), unless specific policy measures are implemented to enhance the development of SMEs in the rural sector.

Location in the northern and north-eastern regions is negatively and significantly correlated with the technical efficiency of aggregate manufacturing SMEs and by size of SME (small or medium), with the exception of medium sized enterprises in the north-eastern region although the result is not statistically significant. It is imperative that the Thai government provide assistance such as human resource development, information technology (IT), appropriate supply of quality inputs, market access and better infrastructure if regional SMEs are to enhance their competitiveness, efficiency and growth. This finding is consistent with the SME promotion plan for 2007 to 2011, which contains strategies to: promote SMEs in the regions and localities; support the creation of networks and connectedness of SMEs in the regions; encourage their employment of technology; and develop their capabilities and business management skills (OSMEP, 2007b). The sub sectoral results also indicate that, for almost all sectors, location in the northern and northeastern regions is negatively and significantly correlated with technical efficiency, although this is not statistically significant for all sectors. It would appear that these regions have significant disadvantages across all sectors for SMEs operating in them. It is important to identify what these key disadvantages are and for regional policy to address them. 
Type of ownership of manufacturing SMEs - individual proprietor, juristic partnership, public and limited company all have a significant positive correlation with technical efficiency in aggregate and by size of SME. This is also the case across all manufacturing sub-sectors. Based on the relative size of coefficients the limited and public limited form of SME ownership is most strongly correlated with the technical efficiency of manufacturing SMEs in aggregate, by size of SME and by manufacturing sub-sector, followed by the juristic partnership and individual forms of ownership. Government policy should focus on encouraging greater access to financial markets by SMEs to encourage limited and public limited forms of ownership through initial public offerings (IPOs), which will also facilitate the growth and size of SMEs.

Government and state ownership is negatively and significantly correlated with the technical efficiency of aggregate manufacturing SMEs and medium sized SMEs, although results by manufacturing sub sector are quite mixed. There is considerable room for improvement in the technical efficiency of government and state owned enterprises in SITC 2, SITC 6 and SITC 8. Reform in these sub-sectors, including that of ownership reform, should be an important policy priority. Finally, cooperative ownership is positively and significantly correlated with the technical efficiency of aggregate manufacturing SMEs and by size of SME. Across manufacturing subsectors cooperative ownership is positively and significantly correlated with the technical efficiency of SMEs in SITC 0 and SITC 5 but negatively correlated for SITC 2. Government policy can usefully encourage the development of SME cooperatives in these sectors as well as in non-municipal and disadvantaged regions.

\section{Conclusions}

Manufacturing SMEs play an important role in the Thai economy. However, our results indicate that they operate with high levels of technical inefficiency. Manufacturing SMEs are caught in a trap where production is heavily dependent upon labor input, predominantly unskilled, and 
involved in low value adding activities. This is particularly so for small firms. They need to become more involved in innovation and technology based activities. Capital input remains of much less importance. It will be critical for SMEs to adopt higher levels of technology and more innovation in their activities (by producing new products, processes and organizational change) if they are to become more efficient, competitive and to move into higher value adding areas of manufacturing activity. This will require upgrading of labor skills. In this context the Thai government has an important role to play in providing training programs, encouraging SME technology upgrading and encouraging innovative activity. As indicated in this study the extent and nature of this should vary by manufacturing sub-sector. A one size fits all policy is unlikely to be successful. Government policy will also be required to tackle apparent and significant regional disadvantages out-with Bangkok and its vicinities

Key factors found to be positively correlated with manufacturing SME efficiency are firm size (economies of scale and scope), age (learning by doing), proportion of the workforce which is skilled, location in towns and cities and particularly location in Bangkok, and type of ownership, whether limited and public limited companies or juristic partnerships. Manufacturing SME policy in Thailand will need to focus, therefore, on: 1) increasing firm size through greater access to inputs such as skilled labor, capital (credit) and technology; 2) upgrading entrepreneurial skills; 3) enhancing worker skills through improvements in education and training programs; 4) tackling rural and regional disadvantages, such as poor local infrastructure, which work against the development of efficient and competitive SMEs; 5) encouraging greater access to finance through initial public offerings (IPOs) that can facilitate firm growth. Such policies should be suitably adapted for differences across manufacturing sub-sectors and by size of SME. 
Table 1: Summary: Definitions of Thai SMEs by Sector

\begin{tabular}{|c|c|c|}
\hline Sectors & $\begin{array}{c}\text { Number of Employees } \\
\text { (Workers) }\end{array}$ & Fixed Asset (THB, Million) \\
\hline \multicolumn{3}{|l|}{ 1. Manufacturing } \\
\hline \multicolumn{3}{|l|}{ 1.1 Small Enterprises } \\
\hline \multirow[t]{2}{*}{ 1.2 Medium Enterprises } & $\leq 50$ & $\leq 50$ \\
\hline & $51-200$ & $>50$ to 200 \\
\hline \multicolumn{3}{|l|}{ 2. Wholesale } \\
\hline \multicolumn{3}{|l|}{ 2.1 Small Enterprises } \\
\hline \multirow[t]{2}{*}{ 2.2 Medium Enterprises } & $\leq 25$ & $\leq 50$ \\
\hline & $26-50$ & $>50$ to 100 \\
\hline \multicolumn{3}{|l|}{ 3. Retail } \\
\hline \multicolumn{3}{|l|}{ 3.1 Small Enterprises } \\
\hline \multirow[t]{2}{*}{ 3.2 Medium Enterprises } & $\leq 15$ & $\leq 30$ \\
\hline & $16-30$ & $>30$ to 60 \\
\hline \multicolumn{3}{|l|}{ 4. Service } \\
\hline \multicolumn{3}{|l|}{ 4.1 Small Enterprises } \\
\hline \multirow[t]{2}{*}{ 4.2 Medium Enterprises } & $\leq 50$ & $\leq 50$ \\
\hline & $51-200$ & $>50$ to 200 \\
\hline
\end{tabular}

Source: the Office of Small and Medium Enterprises Promotion (2003) and Mephokee (2003) 
Table 2: Contribution of Manufacturing SMEs to the Thai Economy, 1994-2008

\begin{tabular}{|c|c|c|c|c|c|c|c|c|c|c|}
\hline Enterprises & 1994 & 1997 & 1999 & 2002 & 2003 & 2004 & 2005 & 2006 & 2007 & 2008 \\
\hline $\begin{array}{l}\text { Business Numbers } \\
\text { SMEs (\% of total } \\
\text { firms) }\end{array}$ & 99.2 & 99.5 & 99.2 & 99.6 & 99.5 & 99.5 & 99.5 & 99.5 & 99.5 & 99.7 \\
\hline $\begin{array}{l}\text { Manufacturing SMEs } \\
(\% \text { of all SMEs) }\end{array}$ & 19.3 & 36.5 & 19 & 21.8 & 18.9 & 30.7 & 30.6 & 30.7 & 28.8 & 20 \\
\hline $\begin{array}{l}\text { Manufacturing SMEs } \\
(\% \text { of all firms })\end{array}$ & 19.1 & 36.3 & 18.8 & 21.7 & 18.8 & 30.5 & 30.4 & 30.6 & 28.7 & 19.9 \\
\hline $\begin{array}{l}\text { SME Employment } \\
\text { SMEs (\% of total } \\
\text { employment) }\end{array}$ & 71.2 & 76.4 & 79.3 & 69 & 60.7 & 75.4 & 75.5 & 76.7 & 76 & 76.2 \\
\hline $\begin{array}{l}\text { Manufacturing SMEs } \\
\text { (\% of total SME } \\
\text { employment) }\end{array}$ & 31.2 & 45.7 & 29.2 & 33.4 & 24.9 & 36.5 & 38.4 & 39 & 39.3 & 38.8 \\
\hline $\begin{array}{l}\text { Manufacturing SMEs } \\
\text { (\% of total } \\
\text { employment) }\end{array}$ & 22.2 & 34.9 & 23.1 & 23.1 & 15.1 & 27.5 & 29 & 29.9 & 29.9 & 29.6 \\
\hline \multicolumn{11}{|l|}{ GDP of SMEs } \\
\hline $\begin{array}{l}\text { SMEs ( } \% \text { of total } \\
\text { GDP) }\end{array}$ & N/A & N/A & 39.4 & 38.8 & 38.1 & 40 & 39.6 & 38.9 & 38.2 & 37.9 \\
\hline $\begin{array}{l}\text { Manufacturing SMEs } \\
(\% \text { of SME GDP) }\end{array}$ & N/A & N/A & 22.8 & 25.3 & 28.8 & 29.1 & 29.5 & 30.3 & 30.7 & 32 \\
\hline $\begin{array}{l}\text { Manufacturing SMEs } \\
(\% \text { of total GDP) }\end{array}$ & N/A & N/A & 9 & 9.8 & 11 & 11.6 & 11.7 & 11.8 & 11.7 & 12.1 \\
\hline $\begin{array}{l}\text { SME Exports } \\
\text { SMEs (\% of total } \\
\text { exports) }\end{array}$ & N/A & N/A & N/A & 45.5 & 32.1 & 29.7 & 29.7 & 30.2 & 29.5 & 31 \\
\hline
\end{tabular}

Sources: the Office of Small and Medium Enterprises Promotion (2001-2008) 


\section{Table 3: Statistics for Hypothesis Tests of the Stochastic Frontier Model and Inefficiency Effects Model by Aggregate Manufacturing SMEs}

\begin{tabular}{lc}
\hline & Aggregate Manufacturing SMEs \\
\hline Null Hypothesis & $(\mathbf{1})$ No technical inefficiency Effects \\
& $\left(H_{0}: \gamma=\delta_{0}=\delta_{1}=\cdots=\delta_{13}=0\right)$ \\
LR Statistics & 19898.80 \\
Critical Value & $\mathbf{2 9 . 9 3 *}$ \\
Decision & Reject $H_{0}$ \\
Null Hypothesis & $\left(H_{0}: \gamma=0\right)$ \\
& 2364.34 \\
LR Statistics & $\mathbf{5 . 4 1 *}$ \\
Critical Value & Reject $H_{0}$ \\
Decision & $\left(H_{0}: \delta_{1}=\delta_{2}=\cdots=\delta_{13}=0\right)$ \\
Null Hypothesis & 16352.48 \\
& $\mathbf{2 2 . 3 6}$ \\
LR Statistics & Reject $H_{0}$ \\
Critical Value & \\
Decision & $(\mathbf{3})$ No joint Inefficiency Variables \\
\hline
\end{tabular}

Note: All critical values of the test statistic are presented at the $1 \%$ level of significance, obtained from a chi-square distribution, except those indicated by *, which contain a mixture of a chi-square distributions, obtained from Table 1 of Kodde and Palm (1986).

\section{Table 4: Statistics for Hypothesis Tests of the Stochastic Frontier Model and Inefficiency Effects Model by Size of SMEs}

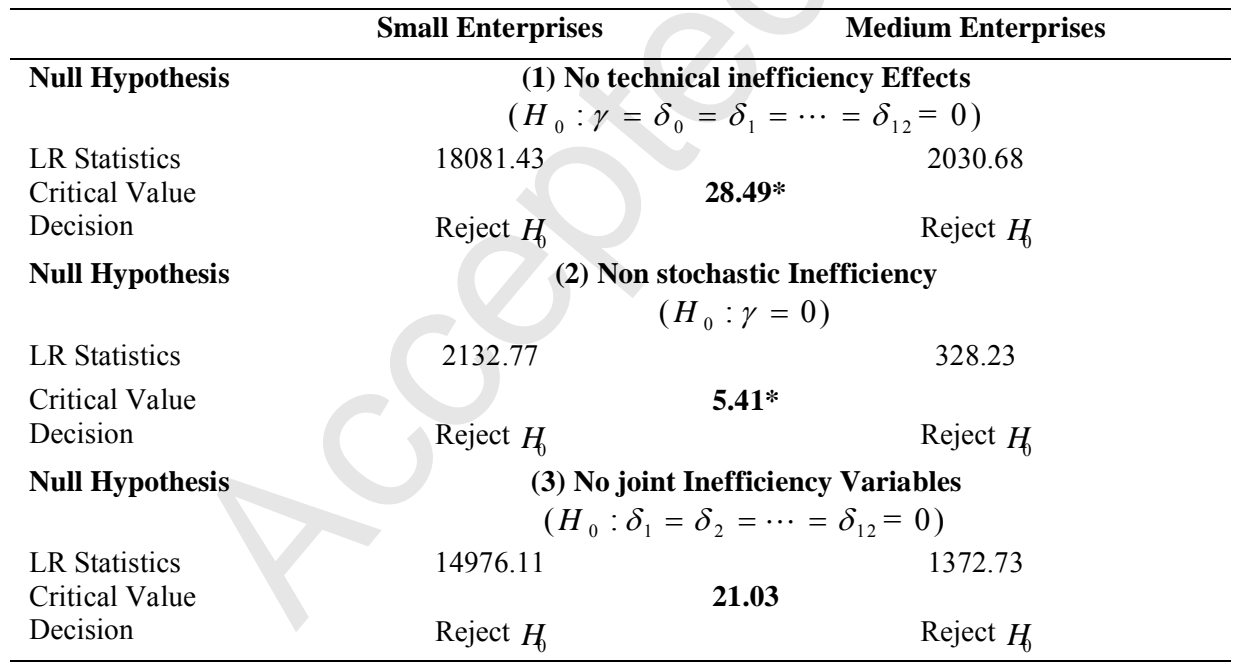

Note: All critical values of the test statistic are presented at the $1 \%$ level of significance, obtained from a chi-square distribution, except those indicated by *, which contain a mixture of a chi-square distributions, obtained from Table 1 of Kodde and Palm (1986). 
Table 5: Statistics for Hypothesis Tests of the Stochastic Frontier Model and Inefficiency Effects Model by SITC Rev.4 (Standard International Trade Classification)

\begin{tabular}{|c|c|c|c|c|c|c|c|c|}
\hline & SITC 0 & SITC 1 & SITC 2 & SITC $3^{22}$ & SITC 5 & SITC 6 & SITC 7 & SITC 8 \\
\hline Null Hypothesis & \multicolumn{8}{|c|}{ (1) No technical inefficiency Effects } \\
\hline & \multicolumn{8}{|c|}{$\left(H_{0}: \gamma=\delta_{0}=\delta_{1}=\cdots=\delta_{13}=0\right)$} \\
\hline LR Statistics & 3291.43 & 322.93 & 2080.48 & - & 2668.74 & 5391.40 & 897.21 & 5687.97 \\
\hline Critical Value & \multicolumn{8}{|c|}{$29.93 *$} \\
\hline Decision & Reject $H_{0}$ & Reject $H_{0}$ & Reject $H_{0}$ & - & Reject $H_{6}$ & Reject $H_{0}$ & Reject $H_{0}$ & Reject $H_{0}$ \\
\hline Null Hypothesis & \multicolumn{8}{|c|}{ (2) Non stochastic Inefficiency } \\
\hline LR Statistics & 418.42 & 44.89 & 248.00 & - & 346.08 & 463.12 & 68.44 & 762.02 \\
\hline Critical Value & \multicolumn{8}{|c|}{$5.41 *$} \\
\hline Decision & Reject $H_{0}$ & Reject $H_{0}$ & Reject $H_{0}$ & - & Reject $H_{6}$ & Reject $H_{0}$ & Reject $H_{0}$ & Reject $H_{0}$ \\
\hline Null Hypothesis & \multicolumn{8}{|c|}{$\begin{array}{l}\text { (3) No joint Inefficiency Variables } \\
\left(H_{0}: \delta_{1}=\delta_{2}=\cdots=\delta_{13}=0\right)\end{array}$} \\
\hline LR Statistics & 2649.87 & 242.43 & 1781.80 & - & 2108.50 & 4659.32 & 748.75 & 4626.56 \\
\hline Critical Value & \multicolumn{8}{|c|}{22.36} \\
\hline Decision & Reject $H_{0}$ & Reject $H_{0}$ & Reject $H_{0}$ & - & Reject $H_{6}$ & Reject $H_{0}$ & Reject $H_{0}$ & Reject $H_{6}$ \\
\hline
\end{tabular}

Note: All critical values of the test statistic are presented at the $1 \%$ level of significance, obtained from $\chi^{2}$ distributions, except those indicated by *, which contain a mixture of $\chi^{2}$ distributions, obtained from Table 1 of Kodde and Palm (1986). SITC 0: Food and live animals, SITC 1: Beverages and tobacco, SITC 2: Crude materials, inedible, except fuels, SITC 3: Mineral fuels, lubricants and related materials, SITC 5: Chemicals and related products, SITC 6: Manufactured goods classified by material, SITC 7: Machinery and transport equipment, SITC 8: Miscellaneous manufactured articles.

\footnotetext{
22 The estimation of SITC 3: Mineral fuels, lubricants and related materials failed to produce significant results due to the estimate of the gamma parameter $(\gamma)$ being 0.0003 , meaning that all deviations are largely attributable to noise. The estimated coefficients for SITC 3 in the technical inefficiency effect models, as specified by equation (3), are not statistically significant for the majority of this category.
} 


\section{Table 6: Maximum Likelihood Estimates for Parameters of the Stochastic Frontier Model and Inefficiency Effects Model by Size of SME}

\begin{tabular}{|c|c|c|c|}
\hline Variables & Aggregate Manufacturing SMEs & Small Enterprises & Medium Enterprises \\
\hline \multirow{2}{*}{ Number of Observations } & 56441 & 49835 & 6606 \\
\hline & Coefficients & Coefficients & Coefficients \\
\hline \multicolumn{4}{|l|}{ Stochastic Frontier Model } \\
\hline Constant & $\begin{array}{c}5.457 * * * \\
(0.032)\end{array}$ & $\begin{array}{c}5.380^{* * * *} \\
(0.038)\end{array}$ & $\begin{array}{c}5.731 * * * \\
(0.14)\end{array}$ \\
\hline Capital & $\begin{array}{l}0.233^{* * *} \\
(0.0020)\end{array}$ & $\begin{array}{l}0.220^{* * *} \\
(0.0030)\end{array}$ & $\begin{array}{l}0.314 * * * \\
(0.0070)\end{array}$ \\
\hline Labor & $\begin{array}{l}0.973 * * * \\
(0.0060)\end{array}$ & $\begin{array}{l}1.045^{* * *} \\
(0.0070)\end{array}$ & $\begin{array}{c}0.683^{* * *} \\
(0.029)\end{array}$ \\
\hline \multicolumn{4}{|l|}{ Inefficiency Effects Model } \\
\hline Constant & $\begin{array}{c}2.949 * * * \\
(0.068)\end{array}$ & $\begin{array}{c}2.571 * * * \\
(0.044)\end{array}$ & $\begin{array}{c}1.569^{* * *} \\
(0.22)\end{array}$ \\
\hline Firm Size (dummy) & $\begin{array}{c}-0.443 * * * \\
(0.057)\end{array}$ & $\begin{array}{l}\text { N/A } \\
\text { N/A }\end{array}$ & $\begin{array}{l}\text { N/A } \\
\text { N/A }\end{array}$ \\
\hline Firm Age (years) & $\begin{array}{l}-0.002 * * \\
(0.0010)\end{array}$ & $\begin{array}{l}-0.002 * * \\
(0.0010)\end{array}$ & $\begin{array}{c}-0.0235^{* * * *} \\
(0.0060)\end{array}$ \\
\hline Skilled Labor (ratio) & $\begin{array}{c}-0.834 * * * \\
(0.031)\end{array}$ & $\begin{array}{c}-0.860 * * * \\
(0.029)\end{array}$ & $\begin{array}{c}0.379 * * * \\
(0.13)\end{array}$ \\
\hline Municipality (dummy) & $\begin{array}{c}-0.358^{* * *} \\
(0.027)\end{array}$ & $\begin{array}{c}-0.390^{* * *} \\
(0.026)\end{array}$ & $\begin{array}{l}0.101 \\
(0.11)\end{array}$ \\
\hline Bangkok (dummy) & $\begin{array}{c}-2.307 * * * \\
(0.17)\end{array}$ & $\begin{array}{c}-2.425^{* * *} \\
(0.21)\end{array}$ & $\begin{array}{c}-2.524 * * * \\
(0.56)\end{array}$ \\
\hline Central \& Vicinity Regions (dummy) & $\begin{array}{l}-0.015 \\
(0.037)\end{array}$ & $\begin{array}{c}0.006 \\
(0.036)\end{array}$ & $\begin{array}{c}-0.515^{* *} \\
(0.24)\end{array}$ \\
\hline Northern Region (dummy) & $\begin{array}{c}0.667 * * * \\
(0.034)\end{array}$ & $\begin{array}{c}0.643^{* * * *} \\
(0.036)\end{array}$ & $\begin{array}{c}2.400^{* * * *} \\
(0.22)\end{array}$ \\
\hline North-eastern Region (dummy) & $\begin{array}{c}0.370 * * * \\
(0.035)\end{array}$ & $\begin{array}{c}0.392 * * * \\
(0.035)\end{array}$ & $\begin{array}{c}-0.130 \\
(0.21)\end{array}$ \\
\hline Individual proprietor (dummy) & $\begin{array}{c}-1.176^{* * *} \\
(0.030)\end{array}$ & $\begin{array}{c}-1.254^{* * *} \\
(0.031)\end{array}$ & $\begin{array}{c}-1.719^{* * *} \\
(0.22)\end{array}$ \\
\hline Juristic partnership (dummy) & $\begin{array}{c}-2.969 * * * \\
(0.090)\end{array}$ & $\begin{array}{c}-3.018^{* * *} \\
(0.10)\end{array}$ & $\begin{array}{c}-3.890^{* * *} \\
(0.32)\end{array}$ \\
\hline Limited \& Public limited company (dummy) & $\begin{array}{c}-4.502^{* * *} \\
(0.14)\end{array}$ & $\begin{array}{c}-4.665 * * * \\
(0.20)\end{array}$ & $\begin{array}{c}-5.439 * * * \\
(0.42)\end{array}$ \\
\hline Government \& State enterprises (dummy) & $\begin{array}{c}0.637 * * * \\
(0.14)\end{array}$ & $\begin{array}{l}0.021 \\
(0.21)\end{array}$ & $\begin{array}{c}1.474 * * * \\
(0.28)\end{array}$ \\
\hline Cooperatives (dummy) & $\begin{array}{c}-1.728 * * * \\
(0.14)\end{array}$ & $\begin{array}{c}-1.906^{* * *} \\
(0.16)\end{array}$ & $\begin{array}{l}-0.705 \\
(0.55)\end{array}$ \\
\hline \multicolumn{4}{|l|}{ Variance Parameters } \\
\hline Sigma-squared & $\begin{array}{c}1.825 * * * \\
(0.029)\end{array}$ & $\begin{array}{c}1.796 * * * \\
(0.032)\end{array}$ & $\begin{array}{c}2.899 * * * \\
(0.23)\end{array}$ \\
\hline Gamma & $\begin{array}{c}\mathbf{0 . 6 5 4} * * * \\
(0.0060)\end{array}$ & $\begin{array}{l}\mathbf{0 . 6 5 3} * * \\
(0.0070)\end{array}$ & $\begin{array}{c}\mathbf{0 . 7 8 7} * * * \\
(0.019)\end{array}$ \\
\hline Log-likelihood Function & -83145.98 & -73992.37 & -8821.86 \\
\hline Simple Average Technical Efficiency ${ }^{23}$ & 0.45 & 0.43 & 0.65 \\
\hline Weighted Average Technical Efficiency ${ }^{24}$ & 0.51 & 0.48 & 0.67 \\
\hline
\end{tabular}

Note: Standard errors are in brackets; $* *$ and $* * *$ indicate that the coefficients are statistically significant at $5 \%$ and $1 \%$, respectively.

\footnotetext{
${ }^{23}$ The simple average technical efficiency is calculated as the sum of technical efficiency scores with respect to total number of firms.

${ }^{24}$ The weighted average technical efficiency is calculated by multiplying individual firm technical efficiency by its weighted contribution to value added, and the sum of these for all firms is then divided by the number of firms in the sample.
} 
Table 7: Maximum Likelihood Estimates for Parameters of the Stochastic Frontier Model and Inefficiency Effects Model by SITC Rev.4 (Standard International Trade Classification)

\begin{tabular}{|c|c|c|c|c|c|c|c|}
\hline Variable & SITC 0 & SITC 1 & SITC 2 & SITC 5 & SITC 6 & SITC 7 & SITC 8 \\
\hline \multirow[t]{2}{*}{ Number of Observations } & 12080 & 1765 & 4608 & 4833 & 17541 & 3892 & 11646 \\
\hline & Coefficients & Coefficients & $\overline{\text { Coefficients }}$ & Coefficients & $\overline{\text { Coefficients }}$ & $\overline{\text { Coefficients }}$ & Coefficients \\
\hline \multicolumn{8}{|l|}{ Stochastic Frontier Model } \\
\hline Constant & $\begin{array}{c}4.620 * * * \\
(0.067)\end{array}$ & $\begin{array}{c}4.253 * * * \\
(0.15)\end{array}$ & $\begin{array}{c}5.725^{* * *} \\
(0.12)\end{array}$ & $\begin{array}{c}5.577 * * * \\
(0.096)\end{array}$ & $\begin{array}{c}5.667 * * * \\
(0.060)\end{array}$ & $\begin{array}{c}6.601 * * * \\
(0.17)\end{array}$ & $\begin{array}{c}6.271^{* * *} \\
(0.067)\end{array}$ \\
\hline Capital & $\begin{array}{c}0.265^{* * *} * \\
(0.0060)\end{array}$ & $\begin{array}{c}0.315^{* * *} \\
(0.017)\end{array}$ & $\begin{array}{c}0.199 * * * \\
(0.010)\end{array}$ & $\begin{array}{l}0.278^{* * * *} \\
(0.0090)\end{array}$ & $\begin{array}{l}0.208 * * * \\
(0.0050)\end{array}$ & $\begin{array}{c}0.177 * * * \\
(0.012)\end{array}$ & $\begin{array}{c}0.1680 * * * \\
(0.0050)\end{array}$ \\
\hline Labor & $\begin{array}{c}1.055^{* * *} \\
(0.015)\end{array}$ & $\begin{array}{c}0.916^{* * *} \\
(0.035)\end{array}$ & $\begin{array}{c}0.996^{* * *} \\
(0.022)\end{array}$ & $\begin{array}{c}0.829 * * * \\
(0.019)\end{array}$ & $\begin{array}{c}0.999 * * * \\
(0.011)\end{array}$ & $\begin{array}{c}0.862 * * * \\
(0.025)\end{array}$ & $\begin{array}{c}0.929^{* * *} \\
(0.014)\end{array}$ \\
\hline \multicolumn{8}{|l|}{ Inefficiency Effects Model } \\
\hline Constant & $\begin{array}{c}3.073^{* * *} \\
(0.16)\end{array}$ & $\begin{array}{c}3.191 * * * \\
(0.39)\end{array}$ & $\begin{array}{c}2.495 * * * \\
(0.27)\end{array}$ & $\begin{array}{c}2.248 * * * \\
(0.26)\end{array}$ & $\begin{array}{c}2.367 * * * \\
(0.13)\end{array}$ & $\begin{array}{c}3.099 * * * \\
(0.47)\end{array}$ & $\begin{array}{c}3.700^{* * *} \\
(0.14)\end{array}$ \\
\hline Firm Size (dummy) & $\begin{array}{c}-0.512 * * * \\
(0.14)\end{array}$ & $\begin{array}{c}-1.719^{* * *} \\
(0.37)\end{array}$ & $\begin{array}{l}0.020 \\
(0.23)\end{array}$ & $\begin{array}{l}0.201 \\
(0.19)\end{array}$ & $\begin{array}{c}-0.190 * * \\
(0.097)\end{array}$ & $\begin{array}{l}0.141 \\
(0.15)\end{array}$ & $\begin{array}{c}-0.728^{* * *} \\
(0.12)\end{array}$ \\
\hline Firm Age (years) & $\begin{array}{c}-0.024 * * * \\
(0.0030)\end{array}$ & $\begin{array}{c}-0.007 \\
(0.010)\end{array}$ & $\begin{array}{c}0.007 * * \\
(0.0030)\end{array}$ & $\begin{array}{c}-0.033 * * * \\
(0.0080)\end{array}$ & $\begin{array}{c}0.004 * * \\
(0.0010)\end{array}$ & $\begin{array}{c}0.002 \\
(0.0030)\end{array}$ & $\begin{array}{c}-0.0004 \\
(0.0020)\end{array}$ \\
\hline Skilled Labor (ratio) & $\begin{array}{c}-0.982 * * * \\
(0.088)\end{array}$ & $\begin{array}{c}-1.322 * * * \\
(0.23)\end{array}$ & $\begin{array}{c}-1.401 * * * \\
(0.10)\end{array}$ & $\begin{array}{c}-0.774 * * * \\
(0.13)\end{array}$ & $\begin{array}{c}-0.628 * * * \\
(0.034)\end{array}$ & $\begin{array}{c}-0.617 * * * \\
(0.094)\end{array}$ & $\begin{array}{c}-0.872 * * * \\
(0.052)\end{array}$ \\
\hline Municipality (dummy) & $\begin{array}{c}-0.548 * * * \\
(0.075)\end{array}$ & $\begin{array}{r}-0.206 \\
(0.15)\end{array}$ & $\begin{array}{c}-0.390 * * * \\
(0.098)\end{array}$ & $\begin{array}{r}-0.226 \\
(0.14)\end{array}$ & $\begin{array}{c}-0.253 * * * \\
(0.039)\end{array}$ & $\begin{array}{l}-0.042 \\
(0.058)\end{array}$ & $\begin{array}{c}-0.389 * * * \\
(0.043)\end{array}$ \\
\hline Bangkok (dummy) & $\begin{array}{c}-4.115^{* * *} \\
(0.47)\end{array}$ & $\begin{array}{c}-4.085^{* * *} \\
(1.5)\end{array}$ & $\begin{array}{c}-3.281 * * * \\
(0.74)\end{array}$ & $\begin{array}{c}-2.465^{* * *} \\
(0.41)\end{array}$ & $\begin{array}{c}-1.127^{* * *} \\
(0.16)\end{array}$ & $\begin{array}{c}-0.712 * * * \\
(0.13)\end{array}$ & $\begin{array}{c}-2.014 * * * \\
(0.19)\end{array}$ \\
\hline Central \& Vicinity Regions (dummy) & $\begin{array}{r}-0.137 \\
(0.10)\end{array}$ & $\begin{array}{r}-0.300 \\
(0.23)\end{array}$ & $\begin{array}{l}0.192 \\
(0.14)\end{array}$ & $\begin{array}{c}-0.054 \\
(0.20)\end{array}$ & $\begin{array}{c}0.089 \\
(0.061)\end{array}$ & $\begin{array}{l}-0.101 \\
(0.097)\end{array}$ & $\begin{array}{l}-0.069 \\
(0.075)\end{array}$ \\
\hline Northern Region (dummy) & $\begin{array}{c}0.688^{* * * *} \\
(0.094)\end{array}$ & $\begin{array}{l}0.298 \\
(0.19)\end{array}$ & $\begin{array}{c}0.796^{* * *} \\
(0.13)\end{array}$ & $\begin{array}{c}2.015^{* * *} \\
(0.20)\end{array}$ & $\begin{array}{c}0.671 * * * \\
(0.063)\end{array}$ & $\begin{array}{c}0.288 * * \\
(0.12)\end{array}$ & $\begin{array}{c}0.404^{* * *} \\
(0.072)\end{array}$ \\
\hline North-eastern Region (dummy) & $\begin{array}{l}-0.049 \\
(0.091)\end{array}$ & $\begin{array}{l}0.414 \\
(0.21)\end{array}$ & $\begin{array}{c}0.881^{* * *} \\
(0.13)\end{array}$ & $\begin{array}{c}0.537^{* * *} \\
(0.19)\end{array}$ & $\begin{array}{c}0.572 * * * \\
(0.061)\end{array}$ & $\begin{array}{c}0.569^{* * *} \\
(0.11)\end{array}$ & $\begin{array}{c}0.221 * * * \\
(0.071)\end{array}$ \\
\hline Individual proprietor (dummy) & $\begin{array}{c}-1.944 * * * \\
(0.10)\end{array}$ & $\begin{array}{c}-1.389 * * * \\
(0.20)\end{array}$ & $\begin{array}{c}-0.966^{* * *} \\
(0.089)\end{array}$ & $\begin{array}{c}-0.973 * * * \\
(0.13)\end{array}$ & $\begin{array}{c}-0.767 * * * \\
(0.038)\end{array}$ & $\begin{array}{c}-1.277 * * * \\
(0.37)\end{array}$ & $\begin{array}{c}-1.040 * * * \\
(0.056)\end{array}$ \\
\hline Juristic partnership (dummy) & $\begin{array}{c}-5.925 * * * \\
(0.40)\end{array}$ & $\begin{array}{c}-1.764 * * * \\
(0.28)\end{array}$ & $\begin{array}{c}-3.378^{* * *} \\
(0.32)\end{array}$ & $\begin{array}{c}-4.223 * * * \\
(0.43)\end{array}$ & $\begin{array}{c}-2.090^{* * *} * \\
(0.10)\end{array}$ & $\begin{array}{c}-2.141 * * * \\
(0.38)\end{array}$ & $\begin{array}{c}-2.687 * * * \\
(0.16)\end{array}$ \\
\hline Limited \& Public limited company (dummy) & $\begin{array}{c}-6.160 * * * \\
(0.44)\end{array}$ & $\begin{array}{c}-4.938^{* * *} \\
(1.1)\end{array}$ & $\begin{array}{c}-4.950 * * * \\
(0.48)\end{array}$ & $\begin{array}{c}-6.034 * * * \\
(0.55)\end{array}$ & $\begin{array}{c}-2.986^{* * *} \\
(0.17)\end{array}$ & $\begin{array}{c}-2.771 * * * \\
(0.38)\end{array}$ & $\begin{array}{c}-3.835^{* * *} \\
(0.18)\end{array}$ \\
\hline Government \& State enterprises (dummy) & $\begin{array}{r}-1.040 \\
(0.78)\end{array}$ & $\begin{array}{c}-3.383^{* *} \\
(1.6)\end{array}$ & $\begin{array}{c}2.128^{* * *} \\
(0.45)\end{array}$ & $\begin{array}{c}-2.545^{* *} \\
(1.0)\end{array}$ & $\begin{array}{c}0.707 * * \\
(0.28)\end{array}$ & $\begin{array}{c}0.000^{25} \\
(1.0)\end{array}$ & $\begin{array}{c}0.736^{* * *} \\
(0.22)\end{array}$ \\
\hline Cooperatives (dummy) & $\begin{array}{c}-2.037 * * * \\
(0.47)\end{array}$ & $\begin{array}{r}-0.071 \\
(0.33)\end{array}$ & $\begin{array}{c}0.266^{* * *} \\
(1.0)\end{array}$ & $\begin{array}{c}-4.193 * * * \\
(0.55)\end{array}$ & $\begin{array}{c}-0.041 \\
(0.47)\end{array}$ & $\begin{array}{c}0.000 \\
(1.0)\end{array}$ & $\begin{array}{c}-0.372 \\
(0.37)\end{array}$ \\
\hline \multicolumn{8}{|l|}{ Variance Parameters } \\
\hline Sigma-squared & $\begin{array}{c}2.345^{* * *} \\
(0.10)\end{array}$ & $\begin{array}{c}1.783 * * * \\
(0.13)\end{array}$ & $\begin{array}{c}2.178 * * * \\
(0.091)\end{array}$ & $\begin{array}{c}2.647 * * * \\
(0.15)\end{array}$ & $\begin{array}{c}1.300^{* * *} \\
(0.031)\end{array}$ & $\begin{array}{c}0.957 * * * \\
(0.080)\end{array}$ & $\begin{array}{c}1.609 * * * \\
(0.050)\end{array}$ \\
\hline Gamma & $\begin{array}{c}\mathbf{0 . 6 4 7} * * * \\
(0.017)\end{array}$ & $\begin{array}{c}\mathbf{0 . 6 6 4} * * * \\
(0.023)\end{array}$ & $\begin{array}{c}\mathbf{0 . 7 5 4} * * * \\
(0.016)\end{array}$ & $\begin{array}{c}\mathbf{0 . 7 6 4} * * * \\
(0.016)\end{array}$ & $\begin{array}{c}\mathbf{0 . 5 2 5} * * * \\
(0.019)\end{array}$ & $\begin{array}{c}\mathbf{0 . 1 8 8} \\
(0.17)\end{array}$ & $\begin{array}{c}\mathbf{0 . 7 0 5} * * * \\
(0.011)\end{array}$ \\
\hline Log-likelihood Function & -18795.46 & -2454.49 & -7105.388 & -6835.92 & -25039.78 & -5267.74 & -16302.97 \\
\hline Simple Average Technical Efficiency ${ }^{26}$ & 0.48 & 0.55 & 0.37 & 0.58 & 0.40 & 0.56 & 0.43 \\
\hline Weighted Average Technical Efficiency $^{27}$ & 0.54 & $\mathbf{0 . 5 8}$ & 0.44 & $\mathbf{0 . 6 3}$ & 0.45 & 0.61 & 0.48 \\
\hline
\end{tabular}

Note: Standard errors are in brackets; $* *$ and $* * *$ indicate that the coefficients are statistically significant at $5 \%$ and $1 \%$, respectively. SE: Small Enterprise, ME: Medium Enterprise, SITC 0: Food and live animals, SITC 1: Beverages and tobacco, SITC 2: Crude materials, inedible, except fuels, SITC 5: Chemicals and related products, SITC 6: Manufactured goods classified by material, SITC 7: Machinery and transport equipment, SITC 8: Miscellaneous manufactured articles.

\footnotetext{
${ }^{25}$ In SITC 7 the estimated coefficients and standard errors shown for the dummy variable for government and state enterprises and cooperatives are insignificant due to the very small number of observations in both categories.

${ }^{26}$ The simple average technical efficiency can be calculated as the sum of technical efficiency scores with respect to total number of firms.

${ }^{27}$ The weighted average technical efficiency is calculated by multiplying individual firm technical efficiency by its weighted contribution to value added, and the sum of these for all firms is then divided by the number of firms in the sample.
} 
Table 8: The Results of Inefficiency Effects Model of Thai Manufacturing SMEs

\begin{tabular}{|c|c|c|c|c|c|c|c|c|c|c|}
\hline Inefficiency Effects & SMEs & $\mathbf{S E}$ & ME & SITC 0 & SITC 1 & SITC 2 & SITC 5 & SITC 6 & SITC 7 & SITC 8 \\
\hline Constant & $+* * *$ & $+* * *$ & $+* * *$ & $+* * *$ & $+* * *$ & $+* * *$ & $+* * *$ & $+* * *$ & $+* * *$ & $+* * *$ \\
\hline Firm Size & $-* * *$ & N/A & N/A & $-* * *$ & $-* * *$ & + & + & $-* *$ & + & $-* * *$ \\
\hline Firm Age & $-* *$ & $-* *$ & $-* * *$ & $-* * *$ & - & $+* *$ & $-* * *$ & $+* *$ & + & - \\
\hline Skilled Labor & $-* * *$ & $-* * *$ & $+* * *$ & $-* * *$ & $-* * *$ & $-* * *$ & -*** & $-* * *$ & $-* * *$ & $-* * *$ \\
\hline Municipality & $-* * *$ & $-* * *$ & + & $-* * *$ & - & $-* * *$ & - & $-* * *$ & - & $-* * *$ \\
\hline Bangkok & $-* * *$ & $-* * *$ & $-* * *$ & $-* * *$ & $-* * *$ & $-* * *$ & $-* * *$ & $-* * *$ & -*** & $-* * *$ \\
\hline Central \& Vicinity Regions & - & + & $-* * *$ & - & - & + & - & + & . & - \\
\hline Northern Region & $+* * *$ & $+* * *$ & $+* * *$ & $+* * *$ & + & $+* * *$ & $+* * *$ & $+* * *$ & $+* *$ & $+* * *$ \\
\hline North-eastern Region & $+* * *$ & $+* * *$ & - & - & + & $+* * *$ & $+* * *$ & $+* * *$ & $+* * *$ & $+* * *$ \\
\hline Individual Proprietor & $-* * *$ & $-* * *$ & $-* * *$ & $-* * *$ & $-* * *$ & $-* * *$ & $-* * *$ & $-* * *$ & $-* * *$ & $-* * *$ \\
\hline Juristic Partnership & $-* * *$ & $-* * *$ & $-* * *$ & $-* * *$ & $-* * *$ & $-* * *$ & $-* * *$ & $-* * *$ & $-* * *$ & $-* * *$ \\
\hline $\begin{array}{l}\text { Limited \& Public Limited } \\
\text { Companies }\end{array}$ & $-* * *$ & $-* * *$ & $-* * *$ & $-* * *$ & $-* * *$ & -*** & & -*** & $-* * *$ & $-* * *$ \\
\hline $\begin{array}{l}\text { Government \& State } \\
\text { Enterprises }\end{array}$ & $+* * *$ & + & $+* * *$ & - & $-* *$ & $+* * *$ & $-* *$ & $+* *$ & + & $+* * *$ \\
\hline Cooperatives & $-* * *$ & _*** & - & $-* * *$ & - & $+* * *$ & $\_* * *$ & - & + & - \\
\hline
\end{tabular}

Note: $* *$ and $* * *$ indicate that the coefficients are statistically significant at $5 \%$ and $1 \%$, respectively. SE: Small Enterprise, ME: Medium Enterprise, SITC 0: Food and live animals, SITC 1: Beverages and tobacco, SITC 2: Crude materials, inedible, except fuels, SITC 5: Chemicals and related products, SITC 6: Manufactured goods classified by material, SITC 7: Machinery and transport equipment, SITC 8: Miscellaneous manufactured articles.

\section{References}

Admassie, A and Matambalya, FAST 2002, 'Technical Efficiency of Small-and Medium-Scale Enterprises: Evidence from a Survey of Enterprises in Tanzania', Eastern Africa Social Science Research Review, vol. 18, no. 2, pp. 1-29.

Amornkitvikai, Y 2011, 'Technical Efficiency Performance of Thai Listed Manufacturing Enterprises', PhD Thesis, School of Economics, Faculty of Commerce, University of Wollongong.

Amornkitvikai, Y and Harvie, C 2011, 'Finance, Ownership, Executive Remuneration, and Technical Efficiency: A Stochastic Frontier Analysis (SFA) of Thai Listed Manufacturing Enterprises', Australasian Accounting Business and Finance Journal, vol. 5, no. 1, pp. 35-55.

Arunsawadiwong, S 2007, 'Productivity Trends in the Thai Manufacturing Sector: The Pre- and Post-Crisis Evidence Relating to the 1997 Economic Crisis', PhD Thesis, School of Economics and Finance, University of St. Andrews.

Batra, G and Tan, H 2003, SME Technical Efficiency and Its Correlates: Cross-National Evidence and Policy Implication, World Bank Institute, Working Paper, Washington DC.

Battese, GE and Coelli, TJ 1995, 'A Model for Technical Inefficiency Effects in a Stochastic Frontier Production Function for Panel Data', Empirical Economics, vol. 20, pp. 325-332.

Battese, GE and Corra, GS 1977, 'Estimation of a Production Frontier Model: With Application to the Pastoral Zone of Eastern Australia', Australian Journal of Agricultural Economics, vol. 21, pp. 169-179. 
Brimble, P, Oldfield, D and Monsakul, M 2002, Policies for SME Recovery in Thailand, The Role of SMEs in National Economies in East Asia, Charles Harvie and Boon-Chye Lee (eds), Edward Elgar, Cheltenham.

Buranajarukorn, P 2006, 'Human Aspects of Quality Management in Development Countries: A Case Study and Model Development for Thai Manufacturing SMEs', PhD thesis, School of Mechanical, Materials and Mechatronic Engineering, University of Wollongong.

Busse, M 2000, 'Do Labour Standards Affect Comparative Advantage? Evidence for Labourintensive Goods', Discussion Paper No. 0142, Centre for International Economic Studies, Adelaide University.

Coelli, TJ 1995, 'Recent Developments in Frontier Modelling and Efficiency Measurement', Australian Journal of Agricultural Economics, vol. 39, no. 3, pp. 219-245.

Coelli, TJ 1996a, A Guide to FRONTIER Version 4.1: A Computer Program for Stochastic Frontier Production and Cost Function Estimation, Working paper 96/07, Centre for Efficiency and Productivity Analysis, Armidale, University of New England.

Coelli, TJ 1996b, A Guide to DEAP Version 2.1: A Data Envelopment Analysis (Computer) Program, Working paper 96/08, Centre for Efficiency and Productivity Analysis, Armidale, University of New England.

Coelli, TJ, Rao, DSP, O'Donnell, CJ and Battese, GE 2005, An Introduction to Efficiency and Productivity Analysis, 2nd edn, Springer, New York.

Dhanani, S and Scholtès, P 2002, Thailand's Manufacturing Competitiveness: Promoting Technology, Productivity and Linkages, 8, United Nations Industrial Development Organization (UNIDO).

Fay, JR 1998, 'What Form of Ownership is Best?', CPA Journal, pp. 1-3.

Ha, TT 2006, 'Entrepreneurial Orientation, Business Strategies and Firm Performance: A Comparative Study of Small and Medium-Scale Enterprises in Vietnam and Thailand', PhD Thesis, Asian Institute of Technology.

Harvie, C 2008, SME Development Strategy in Vietnam, Small and Medium Sized Enterprises in East Asia: Sectoral and Regional Dimensions, Charles Harvie and Boon-Chye Lee (eds), Edward Elgar, Cheltenham.

Harvie, C and Lee, BC (eds) 2002, The Study of Small and Medium Sized Enterprises in East Asia, Globalisation and SMEs in East Asia, Edward Elgar, Cheltenham.

Huang, I-W 2003, 'Importance of SMEs Development in Thailand', Forum of International Development Studies, vol. 23, pp. 159-176.

Jovanovic, B 1982, 'Selection and the Evolution of Industries', Econometrica, vol. 50, no. 3, pp. 649-670.

Kim, S 2003, 'Identifying and Estimating Sources of Technical Inefficiency in Korean Manufacturing Industries', Contemporary Economic Policy, vol. 21, no. 1, pp. 132-144. 
Kodde, DA and Palm, FC 1986, 'Wald Criteria for Jointly Testing Equality and Inequality Restrictions ', Econometrica, vol. 54, no. 5, pp. 1243-1248

Krasachat, W 2000, Measurement of Technical Efficiency in Thai Agricultural Production, The International Conference on the Chao Praya Delta: Historical Development, Dynamics and Challenges of Thailand's Rice Bowl, Bangkok, Thailand, 2-15 December.

Krasniqi, BA 2007, 'Barriers to Entrepreneurship and SME Growth in Transition: The Case of Kosova', Journal of Developmental Entrepreneurship, vol. 12, no. 1, pp. 71-94.

Kumbhakar, S and Lovell, CAK 2000, Stochastic Frontier Analysis, Cambridge University Press, New York.

Le, V and Harvie, C 2010, 'Firm Performance in Vietnam: Evidence from Manufacturing Small and Medium Enterprises', University of Wollongong Economics, Working Paper Series 04-10, pp. $1-33$.

Li, Y and Hu, JL 2002, 'Technical Efficiency and Location Choice of Small and Medium-Sized Enterprises', Small Business Economics, vol. 19, pp. 1-12.

Lundvall, K and Battese, GE 2000, 'Firm Size, Age and Efficiency: Evidence from Kenyan Manufacturing Firms', The Journal of Development Studies, vol. 36, no. 3, pp. 146-163.

Mephokee, C 2003, The Thai SMEs Development Policies: Country Report, Thammasat University, Bangkok.

NSO 2010, Data Summary Report of the 2007 Industrial Census: Whole Kingdom, National Statistical Office of Thailand, accessed 13/05/2010, http://web.nso.go.th/eng/en/stat/indus/data/ds indus07 whole.pdf.

NSO 2011b, The 2007 Industrial Census, National Statistical Office of Thailand, accessed 13/05/2010, http://web.nso.go.th/eng/en/stat/indus/indus00.htm.

ONRCT 2012, Office of National Research Council of Thailand, accessed 15/01/2012, http://www.nrct.go.th/index.php.

OSMEP 2001, Executive Summary of White Paper on SMEs in 2001, Office of Small and Medium Enterprises Promotion, Bangkok.

OSMEP 2003, The White Paper on Small and Medium Enterprises of Thailand in 2003 and Trends 2004, Office of Small and Medium Enterprises Promotion, Bangkok.

OSMEP 2004, The White Paper on Small and Medium Enterprises of Thailand in 2004 and Trends 2005, Office of Small and Medium Enterprises Promotion, Bangkok.

OSMEP 2007a, The White Paper on Small and Medium Enterprises of Thailand in 2007 and Trends 2008, Office of Small and Medium Enterprises Promotion, Bangkok.

OSMEP 2007b, The 2nd SME Promotion Plan (2007-2011), Office of Small and Medium Enterprises Promotion, Bangkok. 
OSMEP 2008, The White Paper on Small and Medium Enterprises of Thailand in 2008 and Trends 2009, Office of Small and Medium Enterprises Promotion, Bangkok.

Pasanen, M 2006, SME Growth Strategies: A Comparison of Young and Long-Lived Firms, International Conference on Business and Information, Singapore, 12-14 July.

Pasanen, M 2007, 'SME Growth Strategies: Organic or Non-Organic?', Journal of Enterprising Culture, vol. 15, no. 4, pp. 317.

Phan, P 2004, 'Trade Liberalisation and Manufacturing Performance in Thailand 1990-2000', PhD Thesis, School of Economics, Faculty of Commerce, University of Wollongong.

Regnier, P 2000, Small and Medium Enterprises in Distress: Thailand, The East Asian Crisis and Beyond, Ashgate Publishing, Burlington.

Ruubel, R and Hazak, A 2011, Company Profitability and Labour Intensity under Different Phases of the Economic Cycle: A Pan-European Empirical Study, 2nd International Conference on Economics, Business and Management, Singapore.

Sahakijpicharn, K 2007, 'Guanxi Network and Business Performance of Sino-Thai SMEs', PhD Thesis, School of Economics, Faculty of Commerce, University of Wollongong.

Saleh, AS and Ndubisi, NO 2008, SME Development in Malaysia: Domestic and Global Challenges, Small and Medium Sized Enterprises in East Asia, Charles Harvie and Boon-Chye Lee (eds), Edward Elgar, Cheltenham.

Sarapaivanich, N 2003, The Use of Financial Information in Financial Decisions of SMEs in Thailand, The Small Enterprise Association of Australia and New Zealand 16th Annual Conference, Ballarat, Australia, 28 September - 1 October.

Tapaneeyangkul, P 2001, Government Policies in Assisting SMEs for Sustainable Development, The Office of Small and Medium Enterprise Promotion, Bangkok.

Theingi 2004, 'The Influence of Marketing Control and a Resource-Based View on Export Performance of SMEs in Thailand', PhD Thesis, University of Western Australia.

Thuvachote, S 2007, Agricultural Cooperatives in Thailand: Innovations and Opportunities in the 21st Century, Department of Cooperatives, Faculty of Economics, Kasetsart University, Bangkok.

Tran, TB, Grafton, RQ and Kompas, T 2008, 'Firm Efficiency in a Transitional Economy:

Evidence from Vietnam', Asian Economic Journal, vol. 22, no. 1, pp. 47-66.

Wiboonchutikula, P 2002, 'Small and Medium Enterprises in Thailand: Recent Trends ', Small Business Economics, vol. 18, pp. 213-226.

Yang, JC 2006, 'The Efficiency of SMEs in the Global Market: Measuring the Korean Performance', Journal of Policy Modeling, vol. 28, pp. 861-876.

Zahid, Z and Mokhtar, M 2007, Estimating Technical Efficiency of Malaysian Manufacturing Small and Medium Enterprises: A Stochastic Frontier Modelling, The 4th SMEs in a Global Economy Conference, University of Wollongong, 9-10 July. 
Re: Thai Manufacturing Small and Medium Sized Enterprise Technical Efficiency: Evidence from Firm-level Industrial Census Data (the article's reference number (ASIECO 906))

- Thai manufacturing SMEs make an important contribution to the economic development of the country.

- This study uses stochastic frontier analysis (SFA) and an inefficiency effects model to analyse the technical efficiency.

- The empirical results reveal that the average technical efficiency is relatively low, which is reducing potential output.

- Results indicate that firm size, firm age, skilled labour, ownership characteristics and location are important factors.

- Key measures to improve Thai manufacturing SMEs are an adequate supply of inputs and training programs for employees. 